Volume 08, Nomor 03: $165-170$

Desember 2019

Naturral Science

\title{
Preferensi Habitat Spesies Kerang Laut (Moluska: Bivalvia) di Ekosistem Intertidal Tanjung Bilik Taman Nasional Baluran
}

\section{(Habitat Preference of Sea Shell Species (Moluska: Bivalvia) in the Intertidal Ecosystem of Tanjung Bilik Baluran National Park)}

\author{
Rendy Setiawan*1, Sudarmadji ${ }^{1}$, Budi Putra Mulyadi ${ }^{1}$, Revika Hilda Hamdani ${ }^{1}$ \\ ${ }^{1}$ Jurusan Biologi, Fakultas MIPA Universitas Jember JI. Kalimantan 37 Sumbersari, Jember 68121, Jawa Timur, \\ Indonesia
}

Keywords: Sea shell, Habitats, Baluran national park

Keywords: Kerang Laut, Habitat, TN Baluran

\begin{abstract}
Shellfish are mollusks that live in the substrate of some aquatic ecosystems. Seashells are an important component of the food chain due to their nutrient recycling function through deposit and suspension feeding. Some species are also able to bioaccumulate heavy metals. In Baluran National Park of East Java, Indonesia, seashells are often used by the local community as foodstuffs and their shells are sold as room decorations, jewelry, and household appliances. Due to overexploitation, it has been suspected that the population density and species diversity of seashells has decreased. This study was carried out in October 2019 at Bilik Beach in Baluran National Park in order to determine the species composition and habitat preferences of seashell species. Random sampling was used to measure the seashell species composition in the study area. Results revealed the presence of 6 orders, 8 families, 11 genera, and 14 species. The calculated species diversity value $\left(\mathrm{H}^{\prime}\right)$ was found to be 2.109 , which indicates medium-level species diversity. The calculated value for species evenness was found to be 0.79 , which indicates low species evenness. Habitat consisted mainly of chunks of dead coral overgrown with algae. Mollusks were often found co-occuring with corals of the Faviidae family, particularly those of the genus Porites.
\end{abstract}

\section{Abstrak}

Kerang merupakan komponen penting yang berperan sebagai pemakan sisa organik yang berada di perairan (deposit feeder) dan pemakan suspensi (suspension feeder) dalam rantai makanan. Beberapa spesies kerang juga dapat berperan dalam mengakumulasi (bioakumulator) logam berat. Di Taman Nasional Baluran, Jawa Timur, Indonesia, kerang sering digunakan oleh masyarakat setempat sebagai bahan dasar makanan dan cangkangnya dijual sebagai dekorasi kamar, perhiasan, dan peralatan rumah tangga. Akibat terjadinya eksploitasi terhadap kerang secara berlebihan, telah diduga bahwa kepadatan populasi dan keanekaragaman spesies kerang telah menurun. Penelitian ini dilakukan pada Oktober 2019 di Pantai Bilik di Taman Nasional Baluran untuk menentukan komposisi spesies dan preferensi habitat spesies kerang. Pengambilan sampel acak digunakan untuk mengukur komposisi spesies kerang di daerah penelitian. Hasil analisis menunjukkan bahwa terdapat adanya 6 ordo, 8 famili, 11 genera, dan 14 spesies. Nilai keanekaragaman spesies yang dihitung menggunakan indeks keanekaragaman jenis $\left(\mathrm{H}^{\prime}\right)$. Hasil yang diperoleh menunjukkan telah ditemukan 
${ }^{*}$ Coresponding Author : rendy.fmipa@unej.ac.id (Phone: 085236636334)
2,109, yang menunjukkan keanekaragaman spesies tingkat sedang. Analisis kemerataan spesies menunjukkan nilai sebesar 0,79 , yang berarti kemerataan spesies rendah. Habitat kerang di Pantai Bilik lebih terfokus pada bongkahan karang mati yang ditumbuhi alga. Moluska sering ditemukan bersama dengan karang dari keluarga Faviidae, terutama yang berasal dari genus Porites.

\section{Latar Belakang}

Moluska merupakan hewan bertubuh lunak yang dilindungi oleh cangkang, namun pada beberapa jenis tidak bercangkang (Brusca \& Brusca, 2003). Salah satu kelas yang termasuk ke dalam filum Moluska adalah Bivalvia (Radiopoetro, 1996; Gosling, 2003). Bivalvia (kerang) memiliki ciri khas berupa dua bagian cangkang yang simetris. Kedua cangkang tersebut disatukan oleh suatu sendi elastis yang disebut ligament pada permukaan bagian dorsal (Rusyana, 2011). Kerang dapat ditemukan hidup di perairan laut, payau, dan tawar.

Kerang dalam ekosistem perairan berperan sebagai pemakan sisa organik (deposit feeder) dan pemakan suspensi (suspension feeder) dalam rantai makanan. Beberapa jenis Bivalvia misalnya kerang hijau (Perna viridis) juga berfungsi sebagai bioakumulator logam berat di perairan (Tjokrokusumo, 2006). Selain sebagai bioakumulator, kerang dapat dimanfaatkan sebagai bahan pangan karena memiliki kandungan protein yang tinggi (Ningsih, 2009). Oleh karena itu, kerang memiliki manfaat ekonomi bagi masyarakat sekitar maupun manfaat ekologi bagi ekosistem dan organisme di ekosistem intertidal. Menurut Goltenboth et al. (2012), ekosistem intertidal merupakan area pasang surut yang memiliki keanekaragaman organisme yang tinggi dan diversitas ekosistem yang bervariasi dibandingkan dengan ekosistem laut lainnya. Kerang laut banyak ditemukan di ekosistem intertidal, salah satunya di ekosistem intertidal Tanjung Bilik Taman Nasional Baluran.

Tanjung Bilik memiliki zona intertidal dengan habitat dan substrat yang bervariasi (Siddiq et al. 2016). yang berperan penting bagi kelangsungan hidup biota perairan (Heide et al. 2014) yaitu sebagai tempat hidup, habitat berperan sebagai tempat berkembang biak dan penyedia makanan. Kerang laut cenderung memilih habitat yang berbeda sesuai dengan karakteristik morfologi, mikrohabitat, dan perbedaan perilaku tiap spesies. Oleh karena itu, kerang laut memiliki preferensi habitat yang berbeda dalam menempati lokasi di ekosistem intertidal. Selain habitat, hal yang juga penting bagi kelangsungan hidup biota perairan yaitu substrat perairan intertidal.
Substrat merupakan permukaan atau media tempat makhluk hidup melekat dan tumbuh. Setiap tipe substrat memiliki kandungan bahan organik yang berbeda-beda, sehingga substrat berpengaruh terhadap preferensi habitat, penyebaran dan komposisi spesies hewan bentik seperti kerang laut (Akhrianti et. al., 2014). Beberapa macam substrat yang ada di Tanjung Bilik yaitu pasir, pasir berlumpur, batu karang, dan karang mati. Diversitas habitat dan substrat yang terdapat di Tanjung Bilik diduga menjadi tempat hidup bagi beberapa jenis kerang laut. Selama ini informasi tentang preferensi habitat spesies kerang laut di Tanjung Bilik belum tersedia. Berdasarkan informasi tersebut, maka perlu dilakukan penelitian tentang preferensi habitat spesies kerang laut di Tanjung Bilik Taman Nasional Baluran, Kabupaten Situbondo.

\section{Bahan dan Metode}

Penelitian dilakukan pada bulan Oktober 2019. Pengambilan sampel dan pengumpulan data dilakukan di ekosistem intertidal Tanjung Bilik Taman Nasional Baluran Kabupaten Situbondo dengan koordinat garis pantai antara $7^{\circ} 45^{\prime} 6.96^{\prime \prime} S$ dan $114^{\circ} 22^{\prime} 26.36^{\prime \prime}$ E sampai $7^{\circ} 45^{\prime} 0.26^{\prime \prime} \mathrm{S}$ dan $114^{\circ} 22^{\prime} 8.87^{\prime \prime}$ E. Identifikasi spesies, deskripsi, dan analisis data kerang dilakukan di Laboratorium Ekologi Jurusan Biologi Fakultas Matematika dan Ilmu Pengetahuan Alam Universitas Jember. Untuk sampel yang belum diketahui jenisnya dilakukan identifikasi lanjutan di laboratorium Malakologi LIPI Cibinong.

Metode yang digunakan adalah Purposive Sampling dengan meletakkan plot berukuran $1 \times 1 \mathrm{~m}^{2}$ secara acak di seluruh ekosistem intertidal bergantung pada keberadaan koloni kerang yang ditemukan. Kerang yang berada pada permukaan substrat diambil dengan cara langsung, sedangkan kerang yang berada di dalam substrat diambil dengan menggunakan bantuan sekop sampai kedalaman maksimal sekitar $25 \mathrm{~cm}$. Hal ini dilakukan karena beberapa spesies kerang mempunyai kemampuan untuk membenamkan diri ke dalam substrat dasar sekitar 5-25 cm (Riniatsih dan Widianingsih, 2007).

Pengambilan sampel diawali dengan menyusuri pantai dari batas tubir hingga mencapai garis pantai. Penyusuran ini dilakukan hingga mencakup seluruh 
wilayah Pantai Bilik pada saat air laut surut. Tujuannya agar tidak mengulang penghitungan terhadap individu yang sama serta mengetahui distribusi setiap spesies kerang yang ditemukan (Setiawan et al., 2018).

Menurut Carpenter dan Niem (1998), identifikasi kerang dilakukan sampai tingkat spesies dengan memperhatikan morfologi cangkang pada masingmasing spesies. Morfologi tersebut meliputi bentuk cangkang, warna, ribs radial, dan umbo. Selain itu bagian internal cangkang yang perlu diamati adalah hinge dan palial line. Penentuan jenis Bivalvia menggunakan buku acuan Dharma (1992), Dharma (1988) dan Carpenter dan Niem (1998). Data kemudian dianalisis menggunakan indeks keanekaragaman spesies Shannon Wiener dan indeks kemerataan spesies (Odum, 1998). Selain jumlah jenis kerang, kondisi habitat tempat ditemukannya juga dicatat. Kondisi habitat digunakan untuk mengetahui preferensi habitat kerang laut. Penilaian kondisi habitat berdasarkan atas kode bentik (benthic code) yang mengacu pada English et al. (1997). Kode yang digunakan adalah sebagai berikut CC (coral covered) untuk substrat berupa tutupan karang hidup, DCA (dead coral algae) untuk substrat berupa batu karang yang mati, FAV (Faviidae) untuk substrat dari famili Faviidae, POR (Porites) untuk substrat dari genus Porites, RB (Rubble) untuk substrat patahanpatahan karang mati, $S$ (Sand) untuk substrat berupa pasir, dan $\mathrm{R}$ (Roots) untuk substrat berupa akar mangrove.

\section{Hasil dan Pembahasan}

Berdasarkan hasil identifikasi diketahui bahwa kerang Laut yang terdapat di Tanjung Bilik Taman Nasional Baluran terdiri atas 6 ordo, 8 famili, 11 genus, dan 14 spesies (Tabel 1) yang tersebar di sepanjang ekosistem intertidal dalam 220 plot. Komposisi spesies kerang laut di ekosistem intertidal Tanjung Bilik Taman Nasional Baluran didominasi oleh jenis Spondylus squamosus dengan jumlah 361 individu (Tabel 1). Kondisi lokasi yang didominasi oleh habitat karang mati sangat cocok untuk mendukung kehidupan $S$. squamosus. Hal ini terkait kemampuannya yang melekat sangat kuat pada karang mati dibandingkan dengan spesies kerang lainnya sehingga dapat bertahan terhadap arus ombak yang besar. Kemampuan lain yang dimiliki oleh $S$. squamosus yaitu mampu melekatkan lebih dari setengah bagian cangkangnya pada substrat sehingga sulit bagi predator untuk memangsanya. Selain itu, keberadaan S. squamosus ditemukan hidup secara mengelompok. Menurut Akhrianti et al., (2014), kerang laut yang hidup secara mengelompok cenderung memiliki kemampuan berkompetisi yang lebih kuat terhadap spesies lainnya dan memudahkan dalam proses reproduksi, sehingga memungkinkan kerang laut tersebut mendominasi spesies lainnya.

Tabel 1. Komposisi Spesies Kerang Laut di Tanjung Bilik Taman Nasional Baluran.

\begin{tabular}{llllc}
\hline Ordo & Famili & Genus & Spesies & Jumlah \\
\hline Arcida & Arcidae & Barbatia & Barbatia foliate & 121 \\
& & Anadara & Anadara antiquate & 87 \\
Cardiida & Cardiidae & Tridacna & Tridacna squamosal & 2 \\
& & & Tridacna crosea & 3 \\
& & & Tridacna maxima & 2 \\
Mytilida & Mytilidae & Modiolus & Modiolus auriculatus & 10 \\
& & Septifer & Septifer bilocularis & 44 \\
Ostreida & Pinnidae & Pinna & Pinna muricata & 179 \\
& Ostreidae & Magallana & Magallana gigas & 52 \\
Pectinida & Isognomonidae & Isognomon & Isognomon isognomon & 30 \\
& & & Isognomon ephippium & 67 \\
Venerida & Spondylidae & Spondylus & Spondylus squamosus & 90 \\
& Veneridae & Gafrarium & Gafrarium pectinatum & 361 \\
\hline & & Total Individu & & 132 \\
\hline
\end{tabular}


Spesies Kerang yang memiliki jumlah individu paling sedikit adalah Tridacna maxima yang hanya ditemukan 2 individu (Tabel 1). Rendahnya jumlah individu tersebut disebabkan oleh tidak adanya alat pelekat (byssus) pada cangkang $T$. maxima sehingga jenis ini tidak dapat beradaptasi terhadap gerakan ombak yang besar. Selain itu, ukuran panjang cangkang T. maxima mencapai $14 \mathrm{~cm}$. Besarnya ukuran cangkang dari jenis ini menyebabkan spesies ini mudah terlihat dan dieksploitasi oleh pengunjung maupun penduduk lokal. Othman et. al. (2010), dalam laporannya menyatakan bahwa famili Cardiidae dikenal memiliki nilai ekonomi yang tinggi karena memiliki daging yang tebal, protein yang tinggi, serta memiliki harga jual yang tinggi. Anggota spesies yang tergolong famili Cardiidae juga memiliki bentuk cangkang unik yang dapat digunakan sebagai bahan dekorasi, perhiasan, dan peralatan rumah tangga sehingga populasinya semakin berkurang di alam (Yusuf, 2009).

\section{Keanekaragaman dan Kemerataan Spesies}

Nilai indeks keanekaragaman spesies kerang laut di Tanjung Bilik adalah 2,109 (Tabel 3.2), menunjukkan bahwa keanekaragaman spesies kerang laut di ekosistem intertidal Tanjung Bilik termasuk dalam kategori sedang. Hal ini menunjukkan bahwa perairan Tanjung Bilik memiliki jumlah spesies Bivalvia yang cukup beragam dengan jumlah individu yang cukup melimpah.

Tabel 2. Nilai Indeks Ekologi Kerang Laut

\begin{tabular}{ll}
\hline \multicolumn{1}{c}{ Indeks Ekologi } & Nilai \\
\hline Keanekaragaman $\left(H^{\prime}\right)$ & 2.109 \\
Kemerataan (E') & 0.799 \\
\hline
\end{tabular}

Faktor yang mempengaruhi nilai indeks keanekaragaman spesies kerang laut di ekosistem intertidal Tanjung Bilik yaitu adanya variasi habitat yang beragam seperti mangrove dan lamun, yang didukung oleh adanya vegetasi makroalga seperti Sargasum sp. yang cukup rapat. Adanya vegetasi yang rapat dapat menahan energi kecepatan arus di suatu perairan sehingga dapat meningkatkan jumlah bahan organik yang terakumulasi pada substrat (Riniatsih dan Kushartono, 2008). Pada lokasi penelitian di daerah tubir yang tidak tertutup oleh vegetasi mangrove, lamun, maupun makroalga menyebabkan pengaruh ombak sangat dominan. Kondisi tersebut mengakibatkan kerang laut jarang ditemukan didaerah ini. Hal ini sesuai dengan pendapat Nybakken (1992), yang menyatakan bahwa perairan dangkal seperti intertidal memiliki unsur pengganggu yang umum yaitu ombak atau pergerakan air yang mengaduk substrat dasar.

Sebaliknya pada daerah intertidal bagian tengah menuju daerah bibir pantai banyak ditemukan habitat karang mati dan makroalga yang cukup rapat. Hal ini mengakibatkan pengaruh arus ombak rendah sehingga spesies kerang laut yang ditemukan didaerah ini lebih beragam. Kondisi berbeda ditemukan pada ekosistem intertidal dibagian bibir pantai yang didominasi substrat pasir dan pasir berlumpur dengan vegetasi lamun yang tidak terlalu rapat sehingga arus ombak masih kuat.

Adanya variasi habitat pada masing-masing daerah sepanjang zona intertidal mengakibatkan adanya spesies kerang laut tertentu yang mendominasi yaitu S. squamosus. Hal ini karena setiap spesies kerang laut memiliki kemampuan adaptasi yang berbeda terhadap habitatnya (Russell dan Hunter, 1983). Namun keberadaan S. squamosus yang mendominasi tersebut menyebabkan munculnya persaingan interspesifik seperti persaingan tempat tinggal, dan makanan. Persaingan tersebut mengakibatkan munculnya tekanan terhadap jenis lain sehingga perkembangannya terbatas dan jumlah individu dari jenis lain menjadi lebih sedikit.

Indeks kemerataan di tanjung Bilik menunjukkan nilai 0,79 yang berarti tergolong dalam kategori rendah. Hal ini menggambarkan bahwa jumlah individu tiap spesies kerang laut di ekosistem intertidal Tanjung Bilik tidak sama atau berbeda pada setiap plot pengambilan sampel. Rendahnya kesamarataan spesies kerang laut di ekosistem intertidal Tanjung Bilik juga dipengaruhi oleh perbedaan kondisi dasar perairan (substrat) sehingga mengakibatkan persebaran dan komposisi spesies kerang laut yang berbeda. Pendapat tersebut didukung oleh laporan Wijayanti (2007), yang menyatakan bahwa substrat di dasar perairan akan menentukan persebaran dan komposisi spesies hewan benthos termasuk kerang laut. Perbedaan persebaran kerang laut pada daerah intertidal ini ditunjukkan oleh suatu spesies kerang laut yang lebih banyak ditemukan didaerah tertentu dibandingkan daerah ekosistem intertidal, sedangkan di bagian bibir pantai dan tubir spesies kerang laut jarang ditemukan. 
Tabel 3. Preferensi Habitat Kerang Laut di Tanjung Bilik Taman Nasional Baluran

\begin{tabular}{|c|c|c|c|c|c|c|c|}
\hline \multirow{2}{*}{ Spesies } & \multicolumn{7}{|c|}{ Preferensi Habitat Spesies Kerang Laut } \\
\hline & CC & DCA & FAV & POR & RB & S & $\mathbf{R}$ \\
\hline Barbatia foliata & & & & & $\sqrt{ }$ & $\sqrt{ }$ & \\
\hline Anadara antiquata & & $\sqrt{ }$ & & & $\sqrt{ }$ & $\sqrt{ }$ & \\
\hline Tridacna squamosa & $\sqrt{ }$ & & & $\sqrt{ }$ & & & \\
\hline Tridacna crocea & $\sqrt{ }$ & & $\sqrt{ }$ & $\sqrt{ }$ & & & \\
\hline Tridacna maxima & & $\sqrt{ }$ & & $\sqrt{ }$ & $\sqrt{ }$ & & \\
\hline Hippopus hippopus & & $\sqrt{ }$ & & & & $\sqrt{ }$ & \\
\hline Modiolus auriculatus & & $\sqrt{ }$ & & & $\sqrt{ }$ & & \\
\hline Septifer bilocularis & & $\sqrt{ }$ & & & $\sqrt{ }$ & & \\
\hline Pinna muricata & & & & & & $\sqrt{ }$ & \\
\hline Magallana gigas & & & & & & & $\sqrt{ }$ \\
\hline Isognomon isognomum & & $\sqrt{ }$ & & & $\sqrt{ }$ & & \\
\hline Isognomon ephippium & & $\sqrt{ }$ & & & $\sqrt{ }$ & & \\
\hline Spondylus squamosus & & $\sqrt{ }$ & & & & & \\
\hline Gafrarium pectinatum & $\sqrt{ }$ & & $\sqrt{ }$ & & & $\sqrt{ }$ & \\
\hline
\end{tabular}

Karakteristik habitat di ekosistem intertidal Tanjung Bilik TN Baluran didominasi oleh substrat karang mati (DCA) dan formasi terumbu karang di bagian tubir. Substrat tempat hidup kerang laut sebagian besar merupakan bongkahan karang mati yang ditumbuhi alga, karang genus Porites, karang hidup, patahan karang, dan karang famili Faviidae. Salah satu spesies kerang yang unik ditemukan di daerah ini adalah keberadaan Kerang Kima (Giant Clam) yang memiliki status langka di alam. Mudjiono (1988) dan Arbi (2010) mengatakan bahwa spesies Kima (Tridacnidae) hidup membenamkan seluruh cangkangnya pada bongkahan karang. Kima mengebor karang dengan dibantu zat kimia untuk melunakkan karang, sehingga dapat hidup pada patahan karang, selama ada celah untuk memasukan byssus. Berbeda dengan Kerang laut golongan tiram (Magallana gigas) yang hanya ditemukan melekat erat pada akar mangrove (Roots) karena spesies ini membutuhkan inang untuk perlekatan byssus.

Kondisi habitat di lokasi Tanjung Bilik memiliki tipe substrat yang bervariasi dengan ekosistem yang cukup baik. Dalam satu lokasi pengamatan, terdapat daerah berpasir, bongkahan karang boulder atau karang masif, serta karang bercabang dan patahan-patahan karang. Substrat berupa daerah berpasir cocok sebagai habitat untuk genus Hippopus (Newman \& Gomez, 2002), sedangkan substrat karang keras cocok untuk Genus Tridacna (Mudjiono, 1988; Knop, 1996). Sedangkan lokasi yang memiliki jumlah individu Kima terendah adalah wilayah dekat pantai yang memiliki substrat pasir dan karang mati. Sedikitnya jumlah Kima yang ditemukan pada lokasi ini kemungkinan besar disebabkan karena waktu penelitian yang relatif lebih singkat dibanding dengan lokasi lain.

\section{Kesimpulan}

Komposisi spesies kerang laut yang terdapat di Tanjung Bilik Taman Nasional Baluran terdiri atas 6 ordo, 8 famili, 11 genus, dan 14 spesies. Nilai indeks keanekaragaman spesies kerang laut di Tanjung Bilik adalah 2,109 yang tergolong kategori sedang. Nilai indeks kesamarataan di tanjung Bilik menunjukkan nilai 0,79 yang berarti tergolong dalam kategori rendah. Substrat tempat hidup kerang laut sebagian besar merupakan bongkahan karang mati yang ditumbuhi alga, karang genus Porites, karang hidup, patahan karang, dan karang famili Faviidae.

\section{Daftar Pustaka}

Akhrianti, A., Bengendan, D.G., \& Budiandi, I.S., 2014, Distribusi dan Preferensi Habitat Bivalvia di Pesisir Perairan Kecamatan Simpang Pesak Kabupaten Belitung Timur. Jurnal IImu dan Teknologi Kelautan Tropis 6(1): 171-185.

Arbi, U.Y., 2010, Kepadatan dan Kondisi Habitat Kerang Kima (Cardiidae: Tridacnae) di Beberapa Lokasi di Perairan Sulawesi Utara. Bawal 3(2): 139-148. 
Brusca, R.C., \& Brusca, G.J., 2003, Invertebrates 2nd Edition, Sinauer Associates, Inc. Massachusetts, Sunderland.

Carpenter, K.E., \& Niem, V.H., 1998, The Living Marine Resources of the Western Central Pacific, Volume 1, Seaweeds, Corals, Bivalves, and Gastropods, Food and Agriculture Organization United Nations, New York.

Dharma, B., 1988, Siput dan Kerang Indonesia (Indonesian shell I), Sahara Graha, Jakarta.

Dharma, B., 1992, Siput dan Kerang Indoensia (Indonesian shell II), Sahara Graha, Jakarta.

English, S., Wilkinson, C.R., \& Baker, V., 1997, Survey Manual for Tropical Marine Resources, Australian Institute of Marine Science, Townsville.

Goltenboth, F., Timous, K.H., Milan, P.P., \& Margraf, J., 2012, Ekologi Asia Tenggara (Kepulauan Indonesia), Salemba Teknika, Jakarta.

Gosling, E., 2003, Bivalve Mollusc: Biology, Ecology, and Culture, Blackwell Publishing, Oxford.

Heide, T.V., Tielens, E., van der Zee, E.M., Weeman, E.J., Holthuijsen, S., Eriksson, B.K., Piersma, T., van de Koppel, J., \& Olff, H., 2014. Predation and Habitat Modification Synergistically Interact to Control Bivalve Recruitment on Intertidal Mudflats. Biological Conservation 172: 163-169.

Insafitri, 2010, Keanekaragaman, Keseragaman, dan Dominansi Bivalvia di Area Buangan Lumpur Lapindo Muara Sungai Porong. Jurnal Kelautan 3(1): 1907-9931.

Knop, D., 1996, Giant Clams, a Comprehensive Guide to the Identification and Care of Tridacnid Clams, Ettlingen, Netherlands.

Mudjiono, 1988, Catatan Beberapa Aspek Kehidupan Kima Suku Tridacnidae (Molusca, Pelecypoda). Oseana 13: 37-47.

Newman, W.A., \& Gomez, E.D., 2002, On the Status of Giant Clams, Relics of Tethys (Mollusk: Bivalvia: Tridacnidae), Proceeding of the $9^{\text {th }}$ International Coral Reef Symposium, Bali, 23-27 October 2000 II, 927-936.

Ningsih, P., 2009, Karakteristik Protein dan Asam Amino Kijing Lokal (Pilsbryoconcha exilis) dari Situ Gede, Bogor Akibat Proses Pengukusan, Skripsi, Fakultas Perikanan dan Ilmu Kelautan Institut Pertanian Bogor, Bogor.
Nybakken, J.W., 1988, Biologi Laut Suatu Pendekatan Ekologis, Alih Bahasa Eidman. M, Bengen. DG, Hutomo. M, Sukardjo, S., Gramedia, Jakarta.

Nybakken, J.W., 1992, Biologi Laut Suatu Pendekatan Ekologis, Alih Bahasa Eidman.M, Bengen. DG, Hutomo. M, Sukardjo, S., Gramedia, Jakarta.

Odum, E.P., 1998. Dasar-Dasar Ekologi, Terjemahan T. Saminga \& B. Srigdanono, Gajdah Mada University Press, Yogyakarta.

Othman, A.S., Goh, G.H.S., \& Todd, P.A., 2010, The Distribution And Status of Giant Clams (Family Tridacnidae). The Raffles Bulletin of Zoology 58(1): 103-111.

Radiopoetro, 1996, Zoologi, Erlangga, Jakarta.

Riniatsih, I., \& Kushartono, E.W., 2008, Substrat Dasar dan Parameter Oseanografi sebagai Penentu Keberadaan Gastropoda dan Bivalvia di Pantai Sluke Kabupaten Rembang. IImu Kelautan 14(1): 50-59.

Riniatsih, I., \& Widianingsih, 2007, Kelimpahan dan Pola Sebaran Kerang-Kerangan (Bivalve) di Ekosistem Padang Lamun, Perairan Jepara. IImu Kelautan 12(1): 53-58.

Russel \& Hunter, W.D., 1983, The Mollusca, Inc. Orlando, New York.

Rusyana, A., 2011, Zoologi Invertebrata, Alfabeta, Bandung.

Setiawan, R., Atmowidi, T., Widayati, KA., \& Purwati, P., 2018, Preferensi Habitat Ophiuroidea di Zona Intertidal Pantai Pancur Taman Nasional Alas Purwo. Jurnal Kelautan 11(2): 151-166.

Siddiq, A.M., Atmowidi, T., \& Qoyyim, I., 2016, The Diversity and Distribution of Holothuroidea in Shallow Waters of Baluran National Park, Indonesia. Biodiversitas 17(1): 55-60.

Tjokrokusumo, S.W., 2006, Bentik Makroinvertebrata sebagai Bioindikator Polusi Lahan Perairan, Jurnal Hidrosfer 1(1): 8-20.

Wijayanti, H.M., 2007, Kajian Perairan di Pantai Kota Bandar Lampung Berdasarkan Komunitas Hewan Makrobenthos, Tesis, Universitas Diponegoro, Semarang.

Yusuf, C., Ambariyanto, \& Hartati, R., 2009, Abundance of Tridacna (Family Tridacnidae) at Seribu Islands and Manado Waters, Indonesia. IImu Kelautan 14(3): 150-154. 